\title{
Coating Deposition by Ion-plasma Sputtering of MAX Phase $\mathrm{Ti}_{2} \mathrm{AlC}$ Target
}

\author{
A.S. Kuprin'ㄹ, T.A. Prikhna ${ }^{2}$, E.N. Reshetnyak ${ }^{1}$, M.A. Bortnitskaya ${ }^{1}$ I.V. Kolodiy ${ }^{1}$, \\ V.A. Belous ${ }^{1}$, S.N. Dub², A.V. Ilchenko', V.B. Sverdun ${ }^{2}$ \\ 1 National Science Center "Kharkov Institute of Physics and Technology", 1, Akademicheskaya St., \\ 61108 Kharkiv, Ukraine \\ ${ }^{2}$ V.N. Bakul Institute for Superhard Materials of the National Academy of Sciences of Ukraine, \\ 2, Avtozavods'ka St., 04074 Kiev, Ukraine
}

(Received 12 May 2020; revised manuscript received 15 October 2020; published online 25 October 2020)

\begin{abstract}
The process of coating deposition by sputtering a target based on the MAX phase $\mathrm{Ti}_{2} \mathrm{AlC}$ using a gas plasma source has been studied. It has been shown that the MAX phase of $\mathrm{Ti}_{2} \mathrm{AlC}$ refers to hard-sputtering materials. With an increase in the sputtering energy of $\mathrm{Ar}^{+}$ions from 400 to $1200 \mathrm{eV}$, the sputtering coefficient of the target based on the MAX phase increases from 0.2 to 0.7 atom/ion. The obtained values are 1.5 times lower than the sputtering coefficients of the target from titanium. Phase transformations occur on the target surface and are associated with the decay of the MAX phase and the selective sputtering of lighter elements due to the bombardment by $\mathrm{Ar}^{+}$ions. It was found that the composition of the deposited coatings is significantly affected by the magnitude of the bias potential on the substrate. With increasing potential in the range from 50 to $200 \mathrm{~V}$, the relative aluminum content in the coatings drops sharply, in favor of titanium from $\mathrm{Ti}: \mathrm{Al}=3.5: 1$ to $\mathrm{Ti}: \mathrm{Al}=48: 1$. Regardless of the composition, a solid solution (Ti, $\mathrm{Al}) \mathrm{C}$ is formed in the coatings with a cubic crystal lattice of the $\mathrm{NaCl}$ type, a crystallite size of $10-15 \mathrm{~nm}$ and an axial type texture. The MAX phase $\mathrm{Ti}_{2} \mathrm{AlC}$ was not detected in the coatings. Received coatings have high hardness and Young's modulus, which increase with decreasing aluminum concentration in the ranges of 21-30 GPa and 290-340 GPa.
\end{abstract}

Keywords: MAX phase, Sputtering, Plasma, Coatings, Structure, Hardness.

DOI: 10.21272/jnep.12(5).05011

PACS numbers: 52.80.Vp, 52.77.Bn, 62.20.Qp, 81

\section{INTRODUCTION}

$\mathrm{Ti}_{2} \mathrm{AlC}$ belongs to the family of ternary nanolaminate compounds known as MAX phases, which have a unique combination of metal and ceramic properties. Like metals, they are electrically and thermally conductive, easily processed by cutting at room temperature, resist crack propagation, are not sensitive to thermal shock, and are ductile at high temperatures. Like ceramics, they have a low density, high elasticity characteristics, and are characterized by high heat and oxidation resistance. The hexagonal structure of the MAX phases consists of layers of transition metal carbides or nitrides separated by monolayers of atoms of IIIA and IVA elements, which leads to the general formula $\mathrm{M}_{n+1} \mathrm{AX}_{n}$ (where $\mathrm{M}=\mathrm{Ti}, \mathrm{V}, \mathrm{Zr}, \mathrm{Hf}, \mathrm{Nb} ; \mathrm{A}=\mathrm{Al}$, Si, Ge, Sn; X=C, N, $n=1,2$ and 3). Lamination at the level of the crystalline structure makes it possible to deform grains locally in the concentration zone of mechanical stresses without macroscopic destruction of the material. This type of deformation is not typical of most ceramic materials and is manifested through delamination, bending, and crushing of grains. This provides materials based on MAX phases with high strength characteristics [1]. The MAX phase of $\mathrm{Ti}_{2} \mathrm{AlC}$ attracts attention with a sufficiently high heat resistance at temperatures up to $1300{ }^{\circ} \mathrm{C}$, which makes it possible to use it in extreme conditions [2] and as protective coatings.

To obtain coatings based on the MAX phases, physical deposition methods are used, such as magnetron sputtering, cathodic arc deposition, and pulsed laser deposition [3]. Most often, Ti2 AlC coatings are obtained by magnetron sputtering [4-7]. The required atomic ratio of elements in coatings $\mathrm{Ti}: \mathrm{Al}: \mathrm{C}=2: 1: 1$ is achieved using three single-element targets $\mathrm{Ti}, \mathrm{Al}$ and $\mathrm{C}$, applying different powers to them, or by sputtering a metal target $\mathrm{Ti}_{50} \mathrm{Al}_{50}$ in an $\mathrm{Ar} / \mathrm{CH}_{4}$ atmosphere [7]. Sputtering only one three-component target of the desired composition can simplify the deposition process. However, with magnetron sputtering of such a target it is not always possible to ensure reproducibility of the elemental composition of the cathode, and the ratio of components in the coatings may differ from the stoichiometric for the MAX phase [4, 6].

Earlier, we showed the effectiveness of using a gas plasma source (GPS) for sputtering metallic materials [8] and deposition of various metal (W, Ta and W-Ta) [9], nitride (TiN, TiSiN) and carbide (TiC, TiSiC) coatings from combined targets $[10,11]$. The distinctive features of the GPS are compared: with the vacuum-arc method - the absence of macroparticles in the coatings, and with the magnetron method - more use of the target material [12].

In this work, we studied the process of coatings deposition by sputtering using of gas plasma source from target based on the MAX phase Ti2AlC, investigated composition, structure and mechanical properties of deposited coatings.

\section{EXPERIMENTAL TECHNIQUE}

A target based on the MAX phase $\mathrm{Ti}_{2} \mathrm{AlC}$ in the form of a disk with a diameter of $60 \mathrm{~mm}$ and a thickness of $5 \mathrm{~mm}$ was obtained by hot pressing from $\mathrm{TiH}_{2}$, TiC, $\mathrm{Al}$ powders according to the procedure described in [2]. The target was used for ion-plasma deposition of coatings on a vacuum unit equipped with a GPS [10]. GPS consists 
of a tubular anode with a diameter of $200 \mathrm{~mm}$ and a length of $380 \mathrm{~mm}$ and a tungsten cathode. A focusing coil is located outside the anode, creating a magnetic field of up to $50 \mathrm{Oe}$. The current of the tungsten spiral is $130 \mathrm{~A}$. The source works as follows: when the working gas is injected into the system, a low-pressure arc discharge with a thermal cathode in crossed electric and magnetic fields is ignited. The target is sputtered by gas ions extracted from the discharge plasma when a negative potential is applied to the target.

Preliminary pumping of the installation was carried out until the vacuum in the chamber was no worse than $0.001 \mathrm{~Pa}$. Ar was used as a working gas, the pressure of which was $0.8 \mathrm{~Pa}$. The experiments were performed at a positive anode potential of $+50 \mathrm{~V}$ and a discharge current of $20 \mathrm{~A}$. The distance between the anode and the target from the MAX phase $\mathrm{Ti}_{2} \mathrm{AlC}$ was $100 \mathrm{~mm}$, and the ion current density on the target was $15 \mathrm{~mA} / \mathrm{cm}^{2}$. The energy of the $\mathrm{Ar}^{+}$ions sputtering the target was set by the value of the negative bias potential $U_{T}$ in the range from -400 to $-1200 \mathrm{~V}$, which was supplied to the target.

Coatings were deposited on polished stainless steel 410 substrates with dimensions of $10 \times 20 \times 1 \mathrm{~mm}$. A negative bias potential $U_{S}$ was applied to the substrates in the range from -50 to $-200 \mathrm{~V}$. The etching rate of the target material was determined by the gravimetric method. The thickness of the coatings was measured by the method of "shadow knives" on a MII-4 microinterferometer. The elemental composition of the target and coatings was monitored by X-ray fluorescence analysis on a Sprut-VM spectrometer, and also by energy dispersive spectroscopy on a JSM-7001F electron scanning microscope.

$\mathrm{X}$-ray diffraction analysis of the target and coatings was carried out on a DRON-4-07 diffractometer in $\mathrm{Cu}-\mathrm{Ka}$ radiation using a selectively absorbing $\mathrm{Ni}$ filter. Phase analysis of the samples and determination of the crystal lattice parameters of the detected phases were carried out according to the Rietveld method. The size $(L)$ of crystallites (coherent diffracting domains) in the coatings was calculated from the Scherrer formula based on the broadening of the (220) peaks.

The nanohardness and Young modulus were measured with a device Nanoindenter G200 by the CSM method [13] at the $\sim 200 \mathrm{~nm}$ depth of penetration of the Berkovich indenter that was less than 0.1 of the coating thickness.

\section{RESULTS AND DISCUSSION}

X-ray diffraction analysis of a hot-pressed target was performed in the initial state and after its sputtering. The obtained diffractograms are presented in Fig. 1, and the results of the phase analysis are shown in Table 1. Fig. 1a illustrates the diffractogram of the target in the initial state. In the initial state, three phases were detected in the target. The main phase is the MAX phase $\mathrm{Ti}_{2} \mathrm{AlC}$ (hexagonal system) with a content of 93 wt. \%. In addition, graphite C (hexagonal system) with a content of $1.8 \mathrm{wt} . \%$ is present in the sample as well as titanium carbide $\mathrm{TiC}$ (cubic system) with a content of 5.2 wt. \%. The crystal lattice parameters of the detected phases are quite close to tabular values. X- ray fluorescence analysis showed that the atomic ratio of titanium and aluminum in the surface layer of the target is $\mathrm{Ti}: \mathrm{Al}=3: 1$.

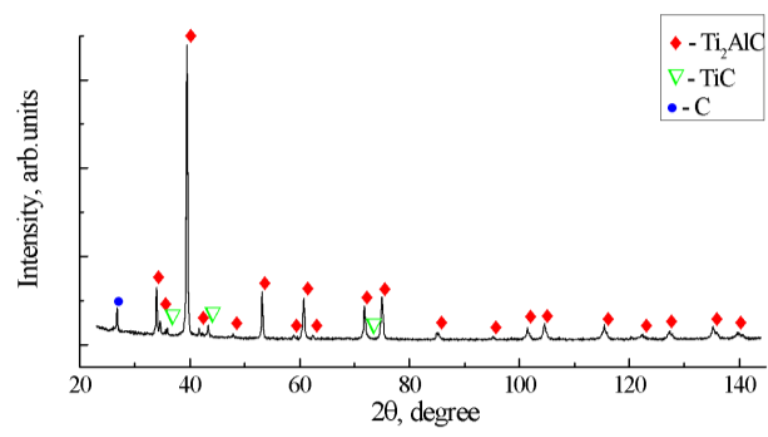

a

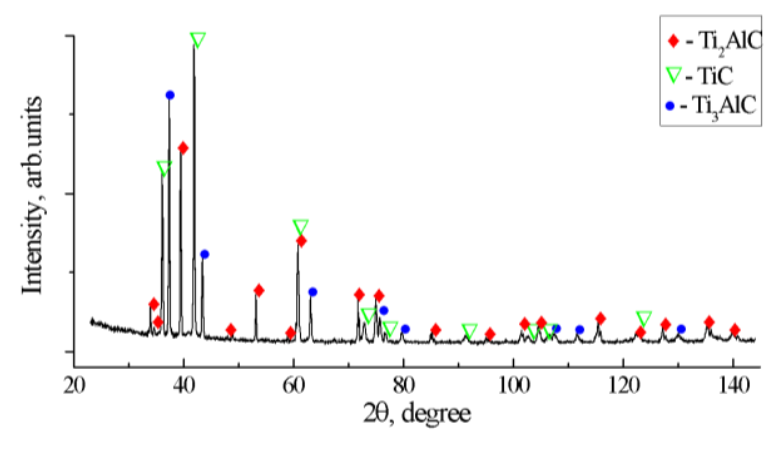

$\mathrm{b}$

Fig. 1 - X-ray diffraction patterns of the target based on the MAX phase $\mathrm{Ti}_{2} \mathrm{AlC}$ before (a) and after (b) sputtering with argon ions

Fig. 1b shows the diffraction pattern of the target after its sputtering with argon ions when the radiation dose reaches $D_{A r} \sim 5 \cdot 10^{21} \mathrm{ion} / \mathrm{cm}^{2}$. It is seen that after sputtering a target, its phase composition changes. The main phase with a weight content of $46 \mathrm{wt}$. \% is titanium carbide TiC. The MAX content of the $\mathrm{Ti}_{2} \mathrm{AlC}$ phase decreases to 26 wt. \%. Also, there is a sample of $\mathrm{Ti}_{3} \mathrm{AlC}$ phase (cubic system) with a weight content of 28 wt. \%. It should be noted that the phase transformations that occur in the target during its sputtering are accompanied by the formation of a texture. In the diffractogram of the sputtered target, the relative intensity of the (200) line of $\mathrm{TiC}$ carbide $\left(2 \theta \sim 41.7^{\circ}\right)$ is higher than the tabulated value for this phase, i.e., there is a predominant orientation of grains by crystallographic planes (h00) parallel to the plane of the target surface. A change in the phase composition of the target surface after its sputtering indicates a decrease in the relative content of $\mathrm{Al}$ and C. X-ray fluorescence analysis confirms this result. The atomic ratio of titanium and aluminum in the surface layer of the sputtered target is $\mathrm{Ti}: \mathrm{Al}=12: 1$.

Change in the elemental composition of the target after sputtering with argon ions is caused by selective sputtering of Al and C. It is known [15] that for multicomponent materials containing elements with different atomic masses, sputtered lighter elements prevail. Intensive ion irradiation leads to the decomposition of the MAX phases into carbides and the formation of 
lower compounds [17]. The appearance of a new $\mathrm{Ti}_{3} \mathrm{AlC}$ phase with a lower content of $\mathrm{Al}$ and $\mathrm{C}$ can be associated with the phase transformation in the target material, since its temperature during the sputtering process was $800-900{ }^{\circ} \mathrm{C}$, which is a sufficient condition for reactions in the Ti-Al-C system [16].

Table 1 - Results of phase analysis of the target before and after sputtering with argon ions

\begin{tabular}{|c|c|c|c|c|c|}
\hline \multirow{2}{*}{ Target } & Phase & Type & \multicolumn{2}{c|}{$\begin{array}{c}\text { L, } \\
\text { wt. } \%\end{array}$} & \multicolumn{2}{c|}{$\begin{array}{c}\text { Lattice pa- } \\
\text { rameters, } \mathrm{nm}\end{array}$} \\
\hline \multirow{4}{*}{ Initial } & & & & $a$ & $c$ \\
\hline & $\mathrm{Ti}_{2} \mathrm{AlC}$ & $194: \mathrm{P}_{3} / \mathrm{mmc}$ & 93.0 & 0.3048 & 1.3639 \\
\cline { 2 - 6 } & $\mathrm{TiC}$ & $225: \mathrm{Fm} 3 \mathrm{~m}$ & 5.2 & 0.4330 & - \\
\cline { 2 - 6 } & $\mathrm{C}$ & $194: \mathrm{P}_{3} / \mathrm{mmc}$ & 1.8 & 0.2464 & 0.6657 \\
\hline $\begin{array}{c}\text { After sputtering } \\
D_{A r}=5 \cdot 10^{21} \\
\text { ion/cm }\end{array}$ & $\mathrm{Ti}_{2} \mathrm{AlC}$ & $194: \mathrm{P} 6_{3} / \mathrm{mmc}$ & 25.8 & 0.3045 & 1.3645 \\
\cline { 2 - 6 } & $\mathrm{TiC}$ & $225: \mathrm{Fm} 3 \mathrm{~m}$ & 45.9 & 0.4305 & - \\
\cline { 2 - 6 } & $\mathrm{Ti}_{3} \mathrm{AlC}$ & $221: \mathrm{Pm} 3 \mathrm{~m}$ & 28.3 & 0.4164 & - \\
\hline
\end{tabular}

There are no data in the literature on the sputtering coefficient of the MAX phase $\mathrm{Ti}_{2} \mathrm{AlC}$, and we only know one work in which magnetron discharge plasma with a target from the MAX phase $\mathrm{Ti}_{2} \mathrm{AlC}$ was studied [4]. Therefore, in addition to structural studies of the target, a determination was made of its sputtering coefficient. Fig. 2 shows the sputtering coefficients of the target with argon ions, depending on their energy, in the range from 400 to $1200 \mathrm{eV}$. The energy of the argon ions was set corresponding to the change in the potential at the target $U_{T}$. A target of pure titanium (99.9\%) of the same area that was sputtered at the same parameters as the target based on the MAX phase $\mathrm{Ti}_{2} \mathrm{AlC}$ was used as a reference material.

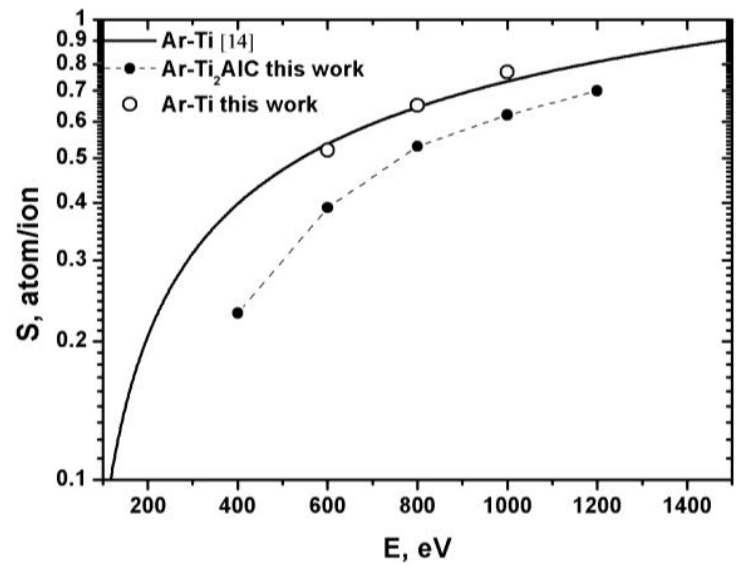

Fig. 2 - Sputtering coefficients of the target based on the MAX phase $\mathrm{Ti}_{2} \mathrm{AlC}$ and the target of $\mathrm{Ti}$ depending on the energy of sputtering argon ions (solid line - data from [14])

As can be seen from Fig. 2, with an increase in the energy of argon ions from 600 to $1000 \mathrm{eV}$, the sputtering coefficient of a titanium target increases from 0.5 to 0.8 atom/ion. The obtained results on the sputtering coefficient of titanium are in good agreement with the literature data [14], which are shown by a solid line in Fig. 2. For a target based on the MAX phase Ti2AlC, the sputtering coefficients are approximately 1.5 times lower than for titanium. Based on this, the MAX phase $\mathrm{Ti}_{2} \mathrm{AlC}$ can be attributed to hard-sputtering materials. With an increase in the energy of argon ions from 400 to $1200 \mathrm{eV}$, the sputtering coefficient of the target based on the MAX phase $\mathrm{Ti}_{2} \mathrm{AlC}$ increases in the range 0.2-0.7 atom/ion.

The results of determining the deposition rate of the coatings obtained by sputtering a target based on the MAX phase $\mathrm{Ti}_{2} \mathrm{AlC}$ are shown in Fig. 3. Dependence of the deposition rate on the value of the sputtering potential of the target $U_{T}$ was obtained at a substrate potential $U_{S}=-50 \mathrm{~V}$ (Fig. 3a). It can be seen that with an increase in $U_{T}$ from 400 to $1000 \mathrm{~V}$, the deposition rate increases almost linearly from 1.5 to $4.5 \mu \mathrm{m} / \mathrm{h}$. With a further increase in the sputtering potential to $1200 \mathrm{~V}$, a decrease in the deposition rate of the coating to $4 \mu \mathrm{m} / \mathrm{h}$ is observed, despite an increase in the sputtering coefficient of the target (see Fig. 2).

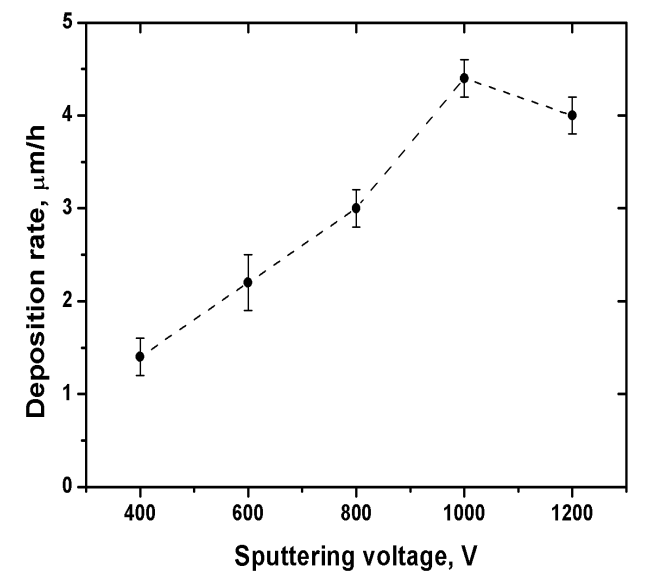

a

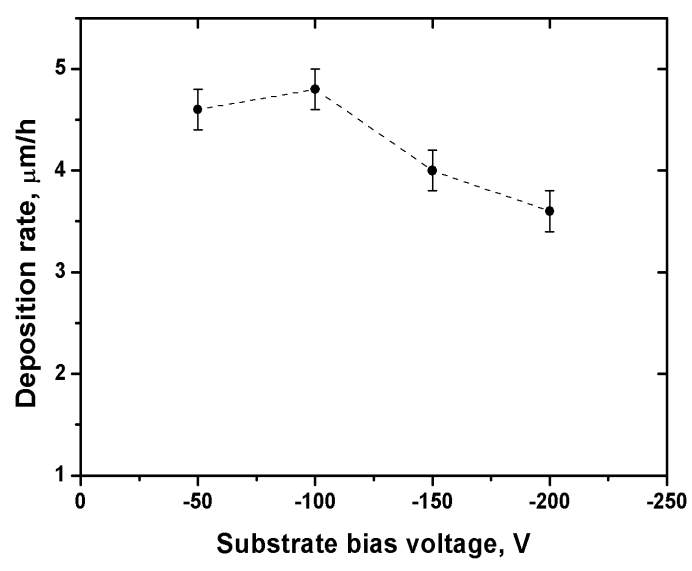

$\mathrm{b}$

Fig. 3 - The deposition rate of the coatings obtained by sputtering a target based on the MAX phase $\mathrm{Ti}_{2} \mathrm{AlC}$ : (a) dependence on the sputtering potential of the target $\left(U_{S}=-50 \mathrm{~V}\right)$; (b) dependence on the substrate potential $\left(U_{T}=-1000 \mathrm{~V}\right)$

The target potential of $1000 \mathrm{~V}$ was chosen for further experiments, since it provided the maximum deposition rate. Fig. $3 \mathrm{~b}$ shows the dependence of the deposition rate on the bias potential on the substrate $U_{S}$. An increase in $U_{S}$ above $100 \mathrm{~V}$ leads to a decrease in the deposition rate of the coatings to $3.5 \mu \mathrm{m} / \mathrm{h}$ at $200 \mathrm{~V}$.

An analysis of the elemental composition of the resulting coatings showed that it differs from the composition of the target. The minimum difference from the target is observed for the coating obtained at the lowest substrate potential $U_{S}=-50 \mathrm{~V}$. The atomic ratio of the 
components is $\mathrm{Ti}: \mathrm{Al}: \mathrm{C}=3.5: 1: 1.5$. With an increase in the potential $U_{S}$, the relative aluminum content in the coatings drops sharply, in favor of titanium. Fig. 4 shows the dependence of the atomic ratio of titanium and aluminum in the coatings on the substrate potential. It can be seen that at a substrate potential of $200 \mathrm{~V}$, the ratio reaches $\mathrm{Ti}: \mathrm{Al}=48: 1$, which differs significantly from the ratio $\mathrm{Ti}: \mathrm{Al}=2: 1$, which is necessary for the formation of the MAX phase $\mathrm{Ti} 2 \mathrm{AlC}$ stoichiometric composition. The fact that the composition of the target and coatings does not match is often described in the literature [4-7].

Fig. 5 shows the diffraction patterns of the coatings obtained at different bias potentials on the substrate in the range from -50 to $-200 \mathrm{~V}$.

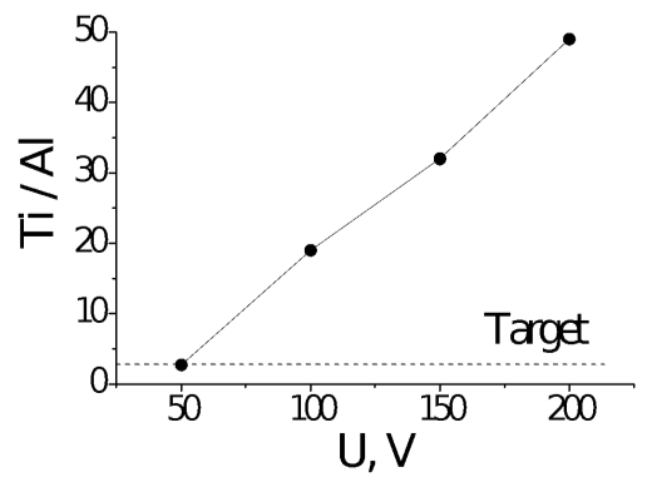

Fig. 4 - Effect of the substrate potential on the ratio of Ti and $\mathrm{Al}$ atoms in the coatings

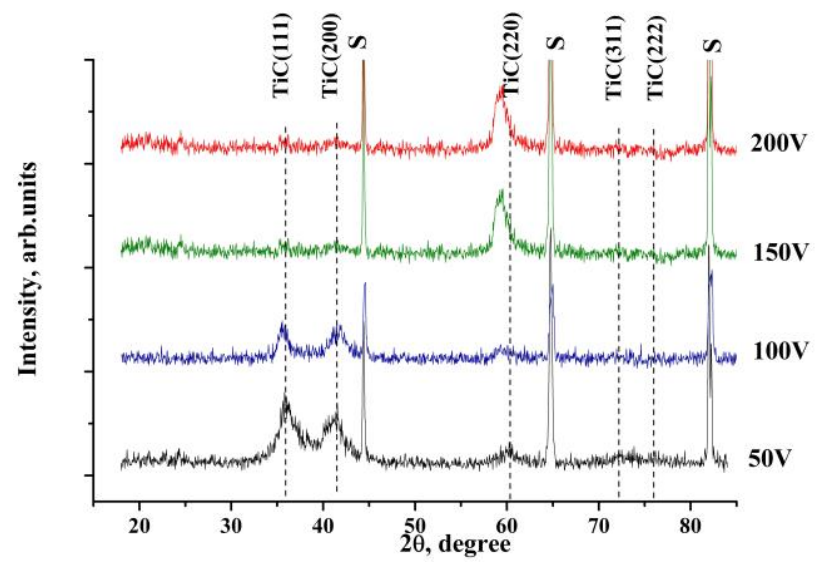

Fig. 5 - Diffraction patterns of the coatings deposited at different bias potentials

On the diffraction patterns, in addition to narrow lines of the substrate $(a-\mathrm{Fe})$, there are broad lines of only the crystalline phase that forms in the coatings solid solution ( $\mathrm{Ti}, \mathrm{Al}) \mathrm{C}$ based on $\mathrm{TiC}$ carbide with a $\mathrm{NaCl}$ type cubic crystal lattice (cubic syngony, 225 lattice type, Fm3m space group). The crystallite size of the carbide in the coatings is $10-15 \mathrm{~nm}$. According to $\mathrm{X}$-ray diffraction analysis, MAX phase $\mathrm{Ti}_{2} \mathrm{AlC}$ in deposited coatings was not detected.

With an increase in the substrate potential, the carbide lines shift toward smaller angles, which indicate an increase in the crystal lattice parameter of the solid solution in the direction normal to the surface. Fig. 6 shows the dependence of the crystal lattice pa- rameter on the bias potential on the substrate during coating deposition. An increase in the parameter in the range $0.4352-0.4405 \mathrm{~nm}$, which is observed with an increase in the potential, correlates with a decrease in the concentration of smaller aluminum atoms in the coatings, which replace large titanium atoms at the sites of the TiC crystal lattice.

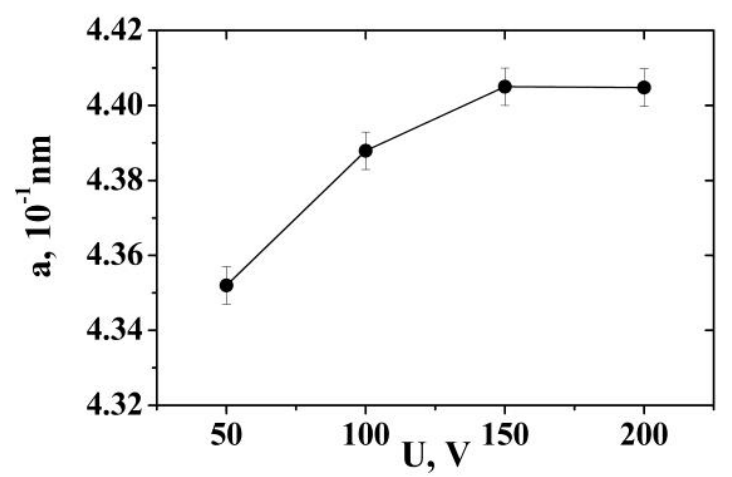

Fig. 6 - Effect of the bias potential on the crystal lattice parameter of titanium carbide in the coatings

The ratio of the intensity of the lines of the solid solution indicates the presence of texture in the coatings. Analysis of the rocking curves showed that an axial type texture is formed in the coatings. Numerical estimates of the preferred orientation in the coatings were carried out by calculating the texture coefficients for the (111), (200) and (220) planes.

The texture coefficient [18] was calculated from the relation:

$$
T_{C}=\left[n I_{m}^{(h k l)} / I_{0}^{(h k l)}\right] /\left[\sum I_{m}^{(h k l)} / I_{0}^{(h k l)}\right],
$$

where $I_{m}(h k l)$ is the measured integrated reflection intensity $(h k l), I_{0}(h k l)$ is the theoretically calculated relative reflection intensity $(h k l)$ for the non-textured powder material, $n$ is the number of recorded reflections, which in this calculation is equal to 3 .

Fig. 7 shows the change in the texture coefficients for $(\mathrm{Ti}, \mathrm{Al}) \mathrm{C}$ reflections with an increase in the bias potential on the substrate. It is seen that with an increase in the potential, the predominant orientation of carbide grains changes from (111) to (220). Similar changes were previously observed for coatings with a $\mathrm{NaCl}$ type structure, which are deposited under ion bombardment conditions. For example, in vacuum-arc coatings $\mathrm{TiN},(\mathrm{Ti}, \mathrm{Al}) \mathrm{N},(\mathrm{Ti}, \mathrm{Cr}) \mathrm{N}$, which are deposited from a highly ionized stream of filtered vacuum-arc plasma, with an increase in the amplitude of the pulse bias potential, the orientation of the grains of cubic nitride changes from (111) to (220), and then to (200), which is accompanied by a decrease in the level of residual compressive stresses [18-21]. Changes are considered as a result of competition between the processes of the appearance and annealing of point defects in the thermal peaks of bombarding ions, which are aimed at minimizing the free energy of the system [22]. General trends are observed, despite the fact that during deposition of coatings by ion sputtering, the degree of ionization of the deposited particle flux is significantly lower than in the case of vacuum-arc deposition [23]. 


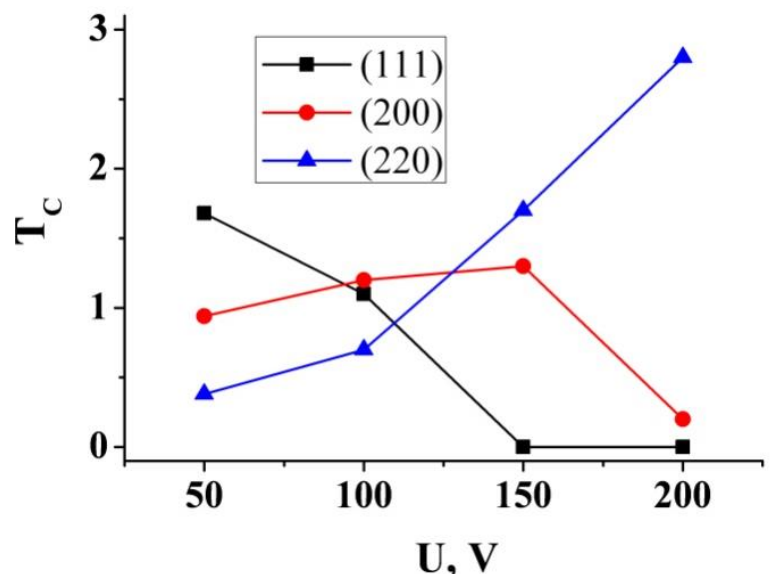

Fig. 7 - Effect of the bias potential on the texture of titanium carbide in the coatings

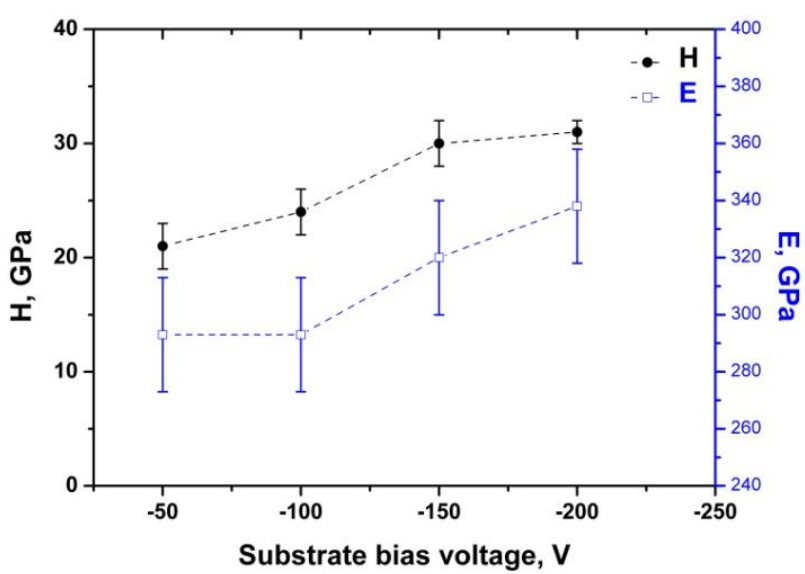

Fig. 8 - Hardness and Young modulus of the coatings depending on the bias potential on the substrate

Thus, the growing surface ion bombardment intensity has decisive importance for the composition and structure of the synthesized coatings in this work. Bombarding particles can be both ionized particles of a sputtered target and argon ions extracted from plasma. A more detailed consideration of this issue requires additional research.

The results of nanoindentation of the obtained coatings are shown in Fig. 8.

All coatings have high mechanical characteristics. The hardness of the coatings increases from 21 to

\section{REFERENCES}

1. M.W. Barsoum, Prog. Solid St. Chem. 28, 201 (2000).

2. T.O. Prikhna, V.Ya. Podhurs'ka, O.P. Ostash, B.D. Vasyliv, V.B. Sverdun, M.V. Karpets, T.B. Serbenyuk, Mater. Sci. 55, 1 (2019).

3. P. Eklund, M. Beckers, U. Jansson, H. Högberg, L. Hultman, Thin Solid Films 518 (2010).

4. J. Frodelius, P. Eklund, M. Beckers, POÅ Persson, H. Högberg, L. Hultman, Thin Solid Films 518 (2010).

5. C. Tang, M. Klimenkov, U. Jaentsch, H. Leiste, M. Rinke, S. Ulrich, M. Steinbruck, H.J. Seifert, M. Stueber, Surf. Coat. Technol. 309 (2017).

6. Y. Li, Gi Zhao, Y. Qian, J. Xu, M. Li, Vacuum 153 (2018).

7. Z. Feng, P. Ke, A. Wang, J. Mater. Sci. Technol. 31 (2015).

8. V.A. Belous, G.I. Nosov, Mater. Sci. Forum 287-288 (1998).
$31 \mathrm{GPa}$ and the Young modulus increases from 293 to $338 \mathrm{GPa}$ with an increase in the bias potential on the substrate from -50 to $-200 \mathrm{~V}$. Compared with the initial target based on $\mathrm{Ti}_{2} \mathrm{AlC}$ [2], coatings have hardness 3-5 times higher which approaches the hardness of TiC when aluminum concentration decreases, which according to the literature is $32 \mathrm{GPa}$. [24].

\section{CONCLUSIONS}

The deposition process of coatings by the method of ion-plasma sputtering of a target based on the MAX phase $\mathrm{Ti}_{2} \mathrm{AlC}$ was studied. It was found that with an increase in the energy of sputtering argon ions from 400 to $1200 \mathrm{eV}$, the sputtering coefficient of the target based on the MAX phase $\mathrm{Ti}_{2} \mathrm{AlC}$ increases from 0.2 to 0.7 atom/ion. The obtained values are 1.5 times lower than the sputtering coefficients of a titanium target, which allows us to attribute the MAX phase Ti2AlC to hard-sputtering materials. It has been shown that, due to ion sputtering, phase transformations associated with the decay of the MAX phase and selective sputtering of lighter elements can occur on the target surface.

It was found that the composition and structure of coatings obtained by sputtering a target based on the MAX phase $\mathrm{Ti}_{2} \mathrm{AlC}$ using a gas plasma source, the magnitude of the bias potential on the substrate has a significant effect. With increasing potential in the range from 50 to $200 \mathrm{~V}$, the relative aluminum content in the coatings drops sharply, in favor of titanium from $\mathrm{Ti}: \mathrm{Al}=3.5: 1$ to $\mathrm{Ti}: \mathrm{Al}=48: 1$. According to X-ray diffraction analysis, a solid solution ( $\mathrm{Ti}, \mathrm{Al}) \mathrm{C}$ is formed in the coatings with a cubic crystal lattice of the $\mathrm{NaCl}$ type, a crystallite size of $10-15 \mathrm{~nm}$ and an axial type texture. With an increase in the bias potential, the lattice parameter of $(\mathrm{Ti}, \mathrm{Al}) \mathrm{C}$ in the coatings, due to a decrease in the aluminum concentration, increases in the range 0.4352-0.4405 $\mathrm{nm}$, and the predominant grain orientation changes from (111) to (220). MAX phase $\mathrm{Ti}_{2} \mathrm{AlC}$ in the coatings was not detected.

The resulting coatings are characterized by high values of hardness and Young modulus, which increase with an increase in the displacement potential in the ranges of $21-30 \mathrm{GPa}$ and $290-340 \mathrm{GPa}$, respectively, which is mainly due to a decrease in the aluminum concentration.
9. V.M. Lunyov, A.S. Kuprin, V.D. Ovcharenko, V.A. Belous, A.N. Morozov, A.V. Пchenko, G.N. Tolmachova, E.N. Reshetnyak, R.L. Vasilenko, Probl. At. Sci. Tech. 101, 1 (2016).

10. V.A. Belous, V.M. Lunyov, G.I. Nosov, A.S. Kuprin, G.N. Tolmachova, I.V. Kolodij, Phys. Surf. Eng. 11, 4 (2013).

11. V.A. Belous, G.I. Nosov, M.A. Bortnitskaya, A.S. Kuprin, A.V. Ilchenko, 4th International Conference "High-purity materials: production, application, properties, 49 (Kharkov: 2017).

12. V.A. Belous, V.M. Lunev, G.I. Nosov, G.N. Tolmacheva, Phys. Surf. Eng. 4, 9 (2011).

13. W.C. Oliver, G.M. Pharr, J. Mater. Res. 19, 1 (2004).

14. Y. Yamamura, H. Tawara, Atomic Data and Nuclear Data Tables 62, 149 (1996). 
15. V.S. Smentkowski, Progr. Surf. Sci. 64 (2000).

16. D. Bandyopadhyay, R.C. Sharma, N. Chakraborti, J. Phase Equil. 21, 179 (2000).

17. J. Ward, S. Middleburgh, M. Topping, A. Garner, D. Stewart, M.W. Barsoum, M. Preuss, P. Frankel, J. Nucl. Mater. 502, 220 (2018).

18. S. Mukherjee, F. Prokert, E. Richter, W. Moeller, Surf. Coat. Technol. 200, 2459 (2005).

19. S.S. Akkaya, V.V. Vasyliev, E.N. Reshetnyak, K. Kazmanl, N. Solak, V.E. Strel'nitskij, M. Urgen, Surf. Coat. Technol. 236, 332 (2013).
20. V.A. Belous, V.V. Vasyliev, V.S. Goltvyanytsya, S.K. Goltvyanytsya, A.A. Luchaninov, E.N. Reshetnyak, V.E. Strel'nitskij, G.N. Tolmacheva, O. Danylina, Surf. Coat. Technol. 206, (2011).

21. V. Vasyliev, A. Luchaninov, E. Reshetnyak, V. Strel'nitskij, B. Lorentz, S. Reichert, V. Zavaleyev, J. Walkowicz, M. Sawczak, Probl. At. Sci. Tech. 6, 244 (2016).

22. D.R. McKenzie, M.M. Bilek, Thin Solid Films. 382, 280 (2001).

23. B.S. Danilin, The use of low-temperature plasma for applying thin films (Moscow: Energoizdat: 1989).

24. H.J. Goldschmidt, Introduction Alloy (Moscow: Mir: 1971).

\title{
Осадження покриття іонно-плазмовим розпиленням мішені з max фази Ti2AlC
}

О.С. Купрін ${ }^{1}$, Т.О. Пріхна ${ }^{2}$, О.М. Решетняк ${ }^{1}$ С.М. Дуб², М.О. Бортницька ${ }^{1}$, І.В. Колодій${ }^{1}$, В.А. Білоус ${ }^{1}$ О.В. Ільченко ${ }^{1}$ В.Б. Свердун ${ }^{2}$

${ }^{1}$ Національний Науковий Центр “Харківський Фізико-технічний Інститут”, вул. Академічна 1, 61108 Харків, Україна

${ }^{2}$ Інститут Надтвердих Матеріалів імені В.М. Бакуля Національної Академії Наук Украӥни, вул. Автозаводська 2, 04074 Київ, Украӥна

\begin{abstract}
Вивчено процес осадження покриттів шляхом розпилення мішені на основі MAX-фрази $\mathrm{Ti}_{2} \mathrm{AlC}$ з використанням джерела газової плазми. Показано, що MAX-фраза $\mathrm{Ti}_{2} \mathrm{AlC}$ відноситься до важкорозпилюемих матеріалів. Зі збільшенням енергії розпилення іонів $\mathrm{Ar}^{+}$з 400 до 1200 еВ коефіціент розпилення мішені на основі МАХ-фрази збільшуеться з 0,2 до 0,7 атом/іон. Отримані значення в 1,5 рази нижчі за коефіціенти розпилення мішені з титану. Фазові перетворення відбуваються на поверхні мішені і пов'язані з розпадом МАХ-фрази та селективним розпиленням більш легких елементів іонами $\mathrm{Ar}^{+}$. Було встановлено, що на склад нанесених покриттів суттево впливає величина потенціалу зміщення на підкладщі. Зі збільшенням потенціалу в діапазоні від 50 до 200 В відносний вміст алюмінію в покриттях різко падає на користь титану від Ti:Al = 3,5:1 до Ti:Al = 48:1. Незалежно від складу, твердий розчин (Ti, Al)C утворюеться в покриттях з кубічною кристалічною решіткою типу $\mathrm{NaCl}$, розміром кристалітів 10-15 нм і текстурою осьового типу. MAX-фраза $\mathrm{Ti}_{2} \mathrm{AlC}$ в покриттях не виявлена. Покриття мають високу твердість і модуль Юнга, які збільшуються зі зниженням концентрації алюмінію в межах 21-30 ГПа та 290-340 ГПа.
\end{abstract}

Ключові слова: МАХ фаза, Розпилення, Плазма, Покриття, Структура, Твердість. 